\title{
A félelem és elkerülési hiedelmek krónikus fájdalomban. A FABQ kérdőív magyar változatának fordítása és validálása
}

\author{
Simoncsics Eszter dr. ${ }^{1}$. Stauder Adrienne dr. ${ }^{2}$ \\ ${ }^{1}$ Egyesített Szent István és Szent László Kórház, Rehabilitáció Centrum, Budapest \\ ${ }^{2}$ Semmelweis Egyetem, Magatartástudományi Intézet, Budapest
}

Bevezetés: A krónikus deréktáji fájdalom az egyik leggyakoribb panasz, amivel a betegek orvoshoz fordulnak. A funkcióromlás hátterében, a testi tünetek mellett, a beteg diszfunkcionális gondolatai, érzelmi lehangoltsága és szociális, kapcsolati problémái azonosíthatók. Az egyik jelentős tényező a mozgástól való félelem, amely elkerülő viselkedésben nyilvánul meg.

Célkitüzés: A kutatás célja a „Fear Avoidance Beliefs Questionnaire” magyar nyelvű változatának (jelölése: FABQ-H) kidolgozása és validálása.

Módszer: A 16 kérdésből álló FABQ kérdőívet lefordítás után 90, legalább három hónapja tartó deréktáji fájdalommal kezelt beteg töltötte ki. A keresztvalidáláshoz a teljes kérdő́́vcsomagot kitöltő 43 beteg FABQ-H-eredményeit öszszevetettük a fájdalom intenzitásával, az Oswestry Derékfájás Funkciómérő Indexszel, a Roland-Morris Derékfájás és Funkciókárosodás Kérdőívvel, a Zung Depresszió Skálával és a Fájdalom Katasztrofizálás Skálával.

Eredmények: A FABQ kérdőív belső konzisztenciája jó volt: Cronbach-alfa-érték 0,8 . A korrelációs vizsgálatok alapján a FABQ egyedül a Fájdalom Katasztrofizálás Skálával korrelált $(\mathrm{r}=0,373, \mathrm{p}=0,014)$.

Következtetés: Vizsgálatunk alapján a FABQ-H kérdőív jól használható, valid mérőeszköz.

Orv Hetil. 2017; 158(24): 949-955.

Kulcsszavak: hiedelmek, krónikus fájdalom, deréktáji fájdalom, félelem, elkerülés

\section{Fear and avoidance beliefs in chronic pain. The translation and validation of the Hungarian version of the FABQ questionnaire}

Introduction: Chronic low back pain is one of the top reasons for seeking medical advice. In the background of the dysfunction besides the somatic pain dysfunctional thinking, negative emotional states, or interpersonal problems can be identified as well. One of the most important factors making the rehabilitation difficult is the fear and avoidance of physical activity.

Aim: The aim of the study was to adapt and validate the Fear Avoidance Beliefs Questionnaire (FABQ-H) in $\mathrm{Hun}$ garian.

Methods: The FABQ ( 16 items) was translated into Hungarian and filled in by 90 patients suffering from low back pain for at least three months. For cross validation the FABQ-H results of 43 patients were compared with pain intensity the Oswestry Low Back Pain Questionnaire (ODI), the Roland-Morris Disability Questionnaire (RDQ), the Zung Depression Scale (Zung) and the Pain Catastrophising Scale (PCS).

Results: The internal consistency of the FABQ-H was good: the Cronbach's alpha was 0.8 . Correlation analysis revealed that the FABQ showed significant correlation only with the Pain Catastrophising Scale $(r=0.373, p=0.014)$. Conclusion: Our results confirm that the FABQ-H is a valid questionnaire that can be well implemented.

Keywords: beliefs, chronic pain, low back pain, fear, avoidance

Simoncsics E, Stauder A. [Fear and avoidance beliefs in chronic pain. The translation and validation of the Hungarian version of the FABQ questionnaire]. Orv Hetil. 2017; 158(24): 949-955.

(Beérkezett: 2017. március 22.; elfogadva: 2017. április 20.) 
A fájdalom a leggyakoribb ok, amivel a betegek orvoshoz fordulnak. Világszerte a krónikus fájdalmak közül a mozgásszervi panaszok, így a gerinc- és ízületi fájdalmak miatt veszik leggyakrabban igénybe az egészségügyi ellátást. Ennek jelentőségét nemcsak az adja, hogy gyakori ellátást igényelnek ezek a betegek, hanem az is, hogy a mozgásszervi elváltozások a funkciókárosodás leggyakoribb okai. Európában a munkaképesség-csökkenés 20\%-a derék- és nyakfájdalommal hozható összefüggésbe [1]. Illés Tamás 2015-ben összefoglaló közleményében részletesen írt a derékfájás kezelésének nemzetközi standardjairól. Ez alapján az akut derékfájás ellátásában fontos a specifikus és nem specifikus panaszok gyors és pontos diagnózisának elkülönítése. Míg a specifikus esetekben a kiváltó okok speciális ellátása szükséges, addig a nem specifikus esetekben fájdalomcsillapító kezelés, valamint korai és aktív mobilizálás a választandó terápiás eljárás. A kezelések elsődleges célja a tünetek hatékony csökkentése mellett megelőzni azok krónikussá válását [2]. Az elhúzódó panaszok és néhol akár a felesleges vizsgálatok során a beteg állapotának megítélésénél a fájdalmat és a funkciókárosodást könnyen összefüggő, együtt változó tünetnek véleményezzük. Ebből az következne, hogyha a fájdalmat hatékonyan kezeljük, a beteg automatikusan visszatér korábbi, aktív életviteléhez. Számos tényező befolyásolja azonban a fájdalom miatti funkcióvesztést (1. ábra). Az egyik fontos meghatározó tényező a félelem és az elkerülő magatartás. Ezt alátámasztják azok az adatok, amelyek alapján a félelem és az elkerülés mintegy

A funkcióvesztés egyik fő oka a mozgástól való félelem. Emiatt a mozgásterápiákban sem tud és nem is akar megfelelöen részt venni.

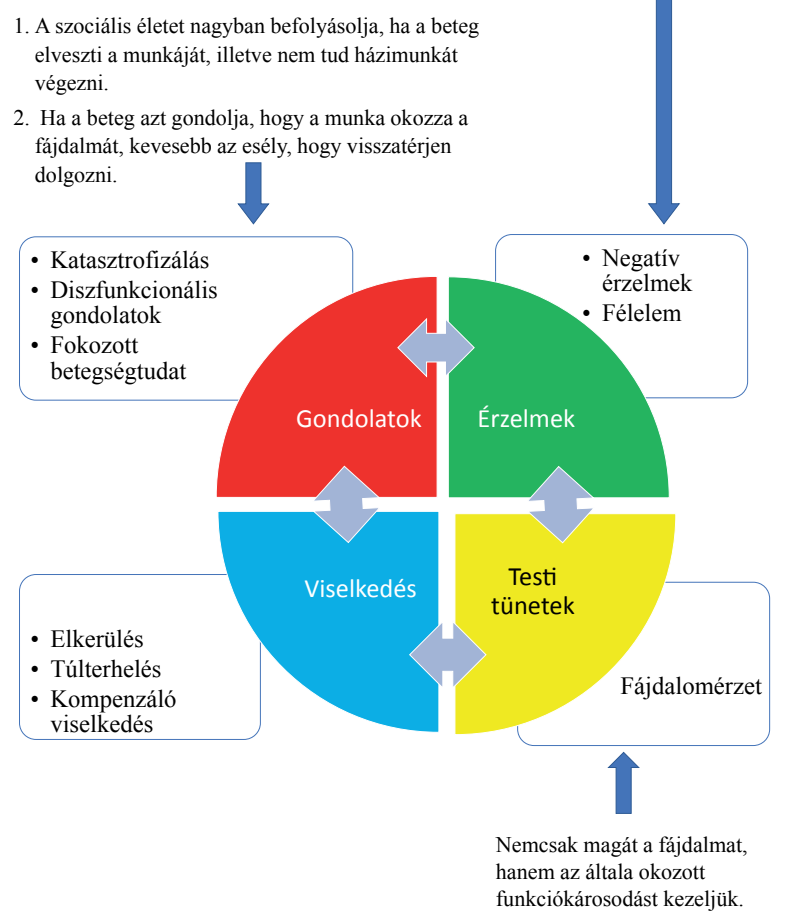

1. ábra $\quad$ A fájdalom miatti funckióvesztésben szerepet játszó tényezók egynegyed részben felelős a funkciókárosodásért (26\%) és a munkából való kiesésért (23\%) [3].

A félelem és elkerülés kiemelt jelentőségét az adja, hogy prognosztikai jelentőséggel bír a munkába visszaállással kapcsolatban [4]. A mozgás kerülése és a fizikai aktivitástól való félelem rontja a rehabilitálhatóságot is. A krónikus fájdalom szindrómák elméleti magyarázataként az szolgál, hogy a fájdalom érzékelésekor kimutathatóan számos agyterület aktiválódik, ami egy egész hálózatot mozgásba lendít. Így a fájdalom nemcsak a szenzoros rendszert, hanem az érzelmi központjainkat is aktiválja, a gondolkodásért felelős területekkel együtt. Ezt nevezzük fájdalommátrixnak. Ezen elmélet szerint bármelyik terület károsodása krónikus fájdalom kialakulását vonhatja maga után. A terápiás lehetőségeinket tudjuk bővíteni, ha a beavatkozás során különböző agyterületek múködésére hatunk. Ezek közül a betegoktatás, illetve a pszichoterápia alkalmazása elsődleges. A fájdalommal kapcsolatos diszfunkcionális gondolatok módosítása során azáltal, hogy a beteg másképp viselkedik, másképp mozog és aktívabban él, a fájdalommátrix-müködés is módosul [5]. Több kutatás regressziós analízissel végzett értékelése során bebizonyosodott, hogy a fájdalmat jelentôs mértékben befolyásolja a depresszió és a betegséggel kapcsolatos viselkedés és hiedelmek [6, 7]. A krónikus fájdalom szindróma kialakulása, illetve terápiája során az agyban neurobiológiai változások mennek végbe, amelynek hátterében az agyi plaszticitás áll [8]. A gyógyulásban lehet ezt kihasználni azáltal, hogy a betegnek egy számára értéket képező célt tüzünk ki. Ezzel aktivizálódnak a különböző agyterületek (frontális lebeny, amygdala, corpus cinguli stb.) és együttesen „dolgoznak meg" a kívánt eredményért.

A munkából való kiesést már nehezebb indokolni a fájdalomnagyság, a depresszió és betegséggel kapcsolatos viselkedések elemzésével, de még itt is szignifikáns összefüggést mutatnak az eredmények. Waddell és mtsai utalnak azon eredményeikre, amelyek alapján a munkából való kiesést inkább a szociális és a munkával kapcsolatos faktorok magyarázzák [9].

\section{Félelem és elkerülési hiedelmek}

Ahhoz, hogy megértsük a félelem jelentőségét a fájdalommal kapcsolatosan, röviden érdemes magáról az érzésról említést tennünk. A félelem egy érzelmi válasz, amelyet a vészhelyzetben fellépő fájdalom indít el és a kiváltó ingert elkerülő viselkedést vált ki [8]. Másként fogalmazva: a fájdalom és a félelem a legerôsebb elkerülő magatartást beindító ösztön az emberben. Az anatómiai ismereteink alapján a fájdalom és a félelem a reticularis rendszerben szoros kapcsolatban van. Habár a félelem és elkerülés előzetes tapasztalás nélkül is megjelenik, életünk során az operáns kondicionálással tanuljuk is ezt a viselkedést. Fordyce véleménye szerint az elkerülő magatartásnak inkább az előzetes feltevésekhez van köze, ezért fennmaradásához egész kicsi megerősítő impulzus 
is elegendő [10]. A félelem miatti elkerülő magatartásnak a fizikai aktivitás csökkenése miatt számos negatív következménye van: romlik a fizikai terhelhetőség, csökken a szellemi frissesség, erősödik a betegszerep, a családi kapcsolatok minősége romlik. A gyógyszerszedéstől való függőség alakulhat ki, és fokozódik az egészségügyi szolgáltatások igénybevétele. A legfontosabb kiemelni mindezeken túl, hogy az elkerülési magatartás sem rövid, sem hosszú távon nem csökkenti a deréktáji fájdalmat [11].

\section{Kérdőívek a félelem és elkerülési hiedelmek mérésére}

A fájdalommal kapcsolatos gondolkodás és viselkedési tényezők vizsgálatának fő módszerei az interjúkészítés, illetve kérdőívek használata. Az elóbbi előnye az alaposság, az utóbbié pedig a könnyủ reprodukálhatóság. Ezzel magyarázható, hogy az elmúlt években számos kérdőivet készítettek. Az elsők között említhető a kapukontroll-elmélet felállításáról ismert Melzack, aki 1975-ben állította össze a McGill Fájdalom Kérdő́ivet [12]. A „Pain and Impairment Relationship Scale” a fájdalom és funkciókárosodás kapcsolatát is méri [13]. A Fájdalom Attitûd kérdőív (Survey of Pain Attitude) a krónikus derékfájós betegek hosszú távú megfigyelésére alkalmazható. Ezen kérdő́ivek azonban csak részben érintik a félelem és elkerülési magatartás területét [14].

Két olyan felmérô eszköz van, amely a mozgástól való félelmet számszerúsíti. Az egyik a Tampa Kinezofóbia Skála (TSK) [15], amelynek sajátossága, hogy az ismételt sérülés veszélyétől való félelmekre is rákérdez. A másik a Fear Avoidance Beliefs Questionnaire (FABQ), amely kérdőívet két célból hozták létre: egyrészt napi klinikai gyakorlati alkalmazásra, másrészt annak vizsgálatára, hogy a fájdalom, a félelem és az elkerülés milyen kapcsolatban áll a funkciókárosodással és a munkából való kieséssel. Ezt a kérdőívet választottuk lefordításra, tekintettel arra, hogy ezt használták az eddigi kutatások döntő többségében $(66,6 \%)$. Felmerül a kérdés, hogy miért pont ezt. A TSK és a FABQ kérdőívek között van átfedés, Swinkels-Meewisse vizsgálatában a korreláció $\mathrm{r}=$ 0,39 volt a TSK és FABQ fizikaiaktivitás-skálák, illetve $\mathrm{r}=0,33$ a TSK és FABQ munkaalskála között [16], míg Crombez erősebb, $r=0,76$, illetve $r=0,53$ korrelációt talált [17]. A FABQ kérdő́ív szélesebb körben való alkalmazása elónyt jelent más kutatásokkal való jobb öszszehasonlíthatóság szempontjából. Másik érv a FABQ kérdőív validálása mellett, hogy a napi aktív tevékenység, illetve maga a munkába állás fontos kimeneti változó mind az egyén, mind a társadalom szintjén. A téves hiedelmek felmérése révén az általános rehabilitációs kezeléseket célzottan ki lehet egészíteni betegoktatással vagy pszichoterápiával is. Ezáltal javítható a beteg együttmúködése, és végül jobb eredményeket érünk el kezelésük során.

\section{Célkitüzés}

Vizsgálatunk célja az volt, hogy magyar nyelven is validáljuk és elemezzük a Félelem és Elkerülés Hiedelmek Kérdőívet (FABQ-H). A FABQ-H használata lehetôvé teszi, hogy kiszúrjük és idôben kezeljük azokat, akiknél a mozgástól való félelem veszélyeztető tényező a fájdalom krónikussá válása szempontjából, ezáltal segítve a rehabilitációs és pszichoterápiás munkát, valamint a krónikus deréktáji fájdalommal kapcsolatos kutatásokat.

\section{Módszer}

A vizsgálat során a validálás nemzetközileg elfogadott standardjait követtük. A folyamatnak két fázisa volt. Az elsőben a kérdő́ív fordítása és nyelvi validálása volt a cél. A másodikban a kulturális adaptálhatóság és klinikai alkalmazhatóság megítélését végeztük.

A Félelem és Elkerülés Hiedelmek Kérdoóiv 16 kérdést tartalmaz. Mindegyik kérdésre hétfokozatú skálán adható válasz: a 0 azt jelenti, hogy egyáltalán nem ért egyet a válasszal, a 6 pedig a teljes egyetértés értéke. A kérdőív pontjainak összegzésén kívül az alpontoknál, az eredeti verziónak megfelelően, a fizikai aktivitásra vonatkozó kérdéseknél négy, a munkával kapcsolatos kérdéseknél hét válasz pontjait adtuk össze. Így az összpontszám 0-66-ig terjedhet, a munkával kapcsolatos félelem pontszáma 0-42-ig, a fizikai aktivitással kapcsolatos félelem pontszáma 0-24-ig.

A kérdőív számos európai és távoli kultúrák által beszélt nyelven is elérhető, többek között németül, franciául, olaszul, japánul, arabul és finnül is, ami a nemzetközi vizsgálatokkal való összehasonlíthatóságot erősíti [18-23].

\section{A kérdöin magyar nyelvere forditása}

Két, mozgásszervi betegségekkel foglalkozó szakorvos a szöveget angolról magyarra fordította, majd a szövegeket összevetve egy kérdő́iv állt össze. Ezt hivatalos szaknyelvi fordító az eredeti nyelvre visszafordította. Az így létrejött kisebb eltéréseket egy harmadik, anyanyelvi szinten beszélő angoltanárral egyeztetve javítottuk ki. A kérdőívet 10, különböző végzettségú egészségügyi dolgozóval ellenóriztettük.

A klinikai alkalmazhatóság megítélése céljából 90, legalább három hónapja deréktáji fájdalomban szenvedő betegnek adtuk oda a FABQ-H tesztet. A vizsgálat első szakaszán túl a divergens validálás megvalósításához 43 pácienssel töltettük ki a funkcionális és diszfunkcionális gondolatokat is tartalmazó kérdő́iveket. A betegeket az Egyesített Szent István és Szent László Kórház Rehabilitációs Centrum Telephelyén osztályos ellátásban részesült betegek közül választottuk ki a megjelenés sorrendjében 2015. október 1. és 2016. július 30 között. A FABQ kérdő́ivet a krónikus fájdalom egyéb aspektusait vizsgáló méróeszközökkel vetettük össze. A fájdalom 
Az összes beteg és az összes kérdőívet kitöltők alapadatainak összehasonlítása

\begin{tabular}{lll}
\hline Adatok & $\mathrm{p}=90$ & $\mathrm{p}=43$ \\
\hline Kor & 60,43 & 58,65 \\
Nemek aránya (\%) & $83 \%$ nő & $81 \%$ nő \\
Kezdő fájdalomérték & 6,64 & 7,02 \\
FABQ-H aktivitás-alskála & 18,11 & 19,02 \\
FABQ-H munkaalskála & 24,1 & 23,37 \\
FABQH összpontszám & 58,9 & 58,02 \\
\hline
\end{tabular}

2. táblázat |A kérdő́ivek eredményei $(\mathrm{n}=43)$

\begin{tabular}{|c|c|c|c|}
\hline Mérőeszköz & $\begin{array}{l}\text { Mérési } \\
\text { intervallum }\end{array}$ & Átlagérték & Szórás \\
\hline Fájdalomintenzitás & $0-10$ & 6,64 & 1,73 \\
\hline $\begin{array}{l}\text { Oswestry Derékfájás } \\
\text { Funkciómérő Index (ODI) }\end{array}$ & $0-50$ & 22,93 & 9,07 \\
\hline $\begin{array}{l}\text { Roland-Morris Derékfájás } \\
\text { és Funkciókárosodás } \\
\text { Kérdőív (RDQ) }\end{array}$ & $0-24$ & 13,27 & 4,16 \\
\hline $\begin{array}{l}\text { Zung Depresszió Skála } \\
\text { (Zung) }\end{array}$ & $20-80$ & 43,88 & 7,58 \\
\hline $\begin{array}{l}\text { Fájdalom Katasztrofizálás } \\
\text { Kérdő́ív (PCS) }\end{array}$ & $0-42$ & 25,24 & 11,25 \\
\hline FABQ-H aktivitás-alskála & $0-24$ & 19,02 & 4,63 \\
\hline FABQ-H munkaalskála & $0-42$ & 23,37 & 12,62 \\
\hline FABQ-H összpontszám & $0-60$ & 58,02 & 13,95 \\
\hline
\end{tabular}

becslésére a 11 pontos Likert-fájdalomskálát (Fájdalom) használtuk, a deréktáji fájdalom funkcionális megítélésére az Oswestry Derékfájás Funkciómérő Indexet [24] ( 10 kérdés, 0-5 Likert-skála) és a Roland-Morris Derékfájás és Funkciókárosodás Kérdőívet (24 kérdés, igennem válaszok) [25], a negatív hangulat megítélésére a Zung Depresszió Skálát (20 kérdés, 1-4 fokozat) használtuk [26]. A katasztrofizáló gondolatokra a Pain Catastrophising Scale magyar nyelvü változatával kérdeztünk rá (13 kérdés, 0-4 Likert-skála) [27, 28].

Beválasztásra azok kerültek, akik megfeleltek a következő kritériumoknak: 18 év feletti életkor, nem: nők és férfiak, tünetek: legalább három hónapja fennálló deréktáji fájdalom mértéke: Fájdalomskálán 4 felett az elmúlt egy hónap átlagában. A páciens beleegyezett a tesztek kitöltésébe. Kizárási kritérium volt, ha specifikus ok állt a fájdalom hátterében: tumor, osteoporoticus fracturák, gyulladás, vagy ha más belgyógyászati, nőgyógyászati vagy urológiai ok magyarázta a panaszokat.

A vizsgálatot a Területi Egészségügyi Tanács 2015. szeptember 11 -én kiadott kutatásetikai engedélye alapján végeztük (száma: 44009-1/2015/EKU).

\section{Statisztikai analízis}

A résztvevők adatait leíró statisztikával értékeltük. A kérdések belső konzisztenciáját Cronbach-alfa-értékkel mértük, amelynek mértéke 0 és 1 közé eshet. A 0,7 feletti érték azt jelzi, hogy a megfogalmazott kérdések egy összefüggő rendszert alkotnak és alkalmasak lekérdezésre, mérésre. A különböző tesztek kapcsolatának vizsgálatához Spearman-korrelációt alkalmaztunk. A statisztikai vizsgálatokat az SPSS programcsomaggal végeztük el. Szignifikáns eltérésnek a p<0,05 értéket tekintettük.

\section{Eredmények}

Vizsgálatban résztvevők jellemzői: a FABQ kérdőívet 90, legalább három hónapja deréktáji fájdalomban szenvedő beteg töltötte ki. A férfi-nő arány 17:73, átlagéletkor 60,34 $\pm 11,53$. Az összes skálát 43 beteg töltötte ki. A két csoport alapadatai szignifikáns különbséget nem mutattak (1. táblázat). A validáláshoz használt mérőeszközök átlageredményei: fájdalom intenzitása 6,64 $\pm 1,73$, ODI 22,93 \pm 9,07, RDQ 13,27 \pm 4,16, Zung $43,88 \pm 7,58$, PCS 25,24 $\pm 11,25$ (2. táblázat).

A kérdések teszt-reteszt megbízhatósági koefficiense $\mathrm{r}=0,758$, ami jó ismételhetőséget jelent.

A kérdőív belső konzisztenciáját vizsgálva az összes kérdést együtt nézve 0,8 értéket kapunk. A fizikai aktivitás alskálát nézve a Cronbach-alpha 0,66, a munkával kapcsolatos félelem alskálára vonatkozóan 0,86 volt.

Továbbgondolásra érdemes a német nyelvű vizsgálat eredményei alapján, hogy a munkától való félelmet két alcsoportra lehet osztani, az egyik reprezentálja a betegek véleményét azokról a munkahelyi környezeti faktorokról, amelyeket a panaszaik kialakulásáért tartanak felelősnek (43\%-a a varianciának). A másik csoport a munkába visszatérés lehetőségével foglalkozik (11,8\%-a a varianciának). Magára a munkahelyi körülményekre vonatkozó, munkahellyel kapcsolatos kérdések a 6., 7., 10. és 11.: „A fájdalmam kialakulásában a munkámnak vagy munkahelyi balesetnek szerepe van”, „A munka fokozta a fájdalmamat”, „A munkám fokozza, illetve fokozhatja a fájdalmamat”, „A munkám árthat a derekamnak". Ezek átlagértékei: $15,07 \pm 7,05$.

A másik csoport kérdései azt mérik fel, hogy milyenek a munkába visszatéréssel és munkavégzéssel kapcsolatos gondolatai a betegnek. A 9., 12., 13., 14., 15., 16. kérdések a következőek:

„A munka, amit végzek, számomra túl nehéz”, „Nem szabadna a mindennapi munkámat a jelenlegi fájdalmammal elvégezni”, „Nem tudom a mindennapi munkámat a jelenlegi fájdalmammal elvégezni”, „Nem tudom a mindennapi munkámat elvégezni, ameddig a fájdalmamat kezelik”, „Nem hiszem, hogy három hónapon belül vissza tudok térni a mindennapi munkámhoz", „Nem hiszem, hogy valaha vissza fogok térni a korábbi munkakörömbe". Ezek átlagértéke 18,86 + 10,73. Ezek figyelembevétele azért fontos, mert megmutatja, ha a 
Kérdőív

FABQ-H - A Félelem és Elkerülés Hiedelmek Kérdőív, az egyes kérdésekre adott válaszok értékei $(\mathrm{n}=90)$

Lehetséges válaszok a fizikai aktivitással kapcsolatos kérdésekre

1. A fájdalmam oka a fizikai aktivitás.

2. A fájdalmamat a fizikai aktivitás fokozza.

4,94

3. A fizikai aktivitás árthat a gerincemnek.

4,22

4. Nem szabad olyan fizikai aktivitást végeznem, ami a fájdalmamat fokozhatja.

5. Nem tudok olyan fizikai aktivitást végezni, amely fokozhatja a fájdalmamat.

Lehetséges válaszok a munkával kapcsolatos kérdésekre

6. A fájdalmam kialakulásában a munkámnak vagy munkahelyi balesetnek szerepe van.

7. A munka fokozta a fájdalmamat.

8. Igényt tartok arra, hogy tekintettel legyenek fájdalmamra.

9. A munka, amit végzek, számomra túl nehéz.

10. A munkám fokozza, illetve fokozhatja a fájdalmamat.

11. A munkám árthat a derekamnak.

12. Nem szabadna a mindennapi munkámat a jelenlegi fájdalmammal elvégezni.

13. Nem tudom a mindennapi munkámat a jelenlegi fájdalmammal elvégezni.

14. Nem tudom a mindennapi munkámat elvégezni, ameddig a fájdalmamat kezelik.

15. Nem hiszem, hogy három hónapon belül vissza tudok térni a mindennapi munkámhoz.

16. Nem hiszem, hogy valaha vissza fogok térni a korábbi munkakörömbe.

Összpontszám:

munkahellyel kapcsolatos problémák állnak a panaszok fennmaradásának hátterében. Valamint előrevetítheti annak valószínúségét, hogy újra munkába fog-e állni a páciens.
A konvergens, illetve divergens validitás meghatározására a FABQ kérdő́iv és egyéb, a krónikus derékfájás vizsgálatára használt kérdő́ivekkel való korrelációját vizsgáltuk. A FABQ-összpontszám egyedül a fájdalomkatasztrofizálással mutatott szignifikáns együtt mozgást $(\mathrm{r}=0,373, \mathrm{p}=0,014)$. Ugyanakkor a félelem, az elkerülés és a hiedelmek nem mutattak összefüggést sem az életkorral, sem a fájdalom intenzitását, a funkciókárosodást, illetve a hangulati nyomottságot mérő kérdőívekkel (3. táblázat).

\section{Megbeszélés}

A deréktáji fájdalom krónikussá válásában a fájdalomtól való félelem, a fizikai aktivitással és munkavégzéssel kapcsolatos téves hiedelmek fontos szerepet játszanak. Ugyanakkor számos vizsgálat igazolja, hogy az elkerülési magatartás, az inaktivitás sem rövid, sem hosszú távon nem csökkenti a deréktáji fájdalmat. A Fear Avoidance Beliefs Questionnaire (FABQ-H) kérdő́ív magyar verziójának kidolgozásával egy új mérőeszköz áll a klinikusok rendelkezésére, amely elősegíti a félelmek és az elkerülő magatartás felmérését a mindennapi betegellátás során (l. Kérdöín). A problémák korai felismerése a rehabilitáció tervezését is hatékonyabbá teszi.

Jelen vizsgálatban a FABQ-H kérdőív nyelvi validitását egészségügyi szakdolgozók és betegek bevonásával teszteltük. A kérdések világosak, jól érthetônek bizonyultak, a kérdőív kitöltése nem jelentett nehézséget a betegeknek. A validálás során több pszichometriai és funkcionális teszttel vetettük össze a FABQ-H-t.

Hipotézisünknek megfelelően a fájdalom nagysága nem függött össze a diszfunkcionális gondolatokkal, ami alátámasztja, hogy nem maga a testi érzet okozza a téves elképzeléseket, illetve az elkerülő magatartást. A kérdőív divergens validálását a fájdalom nagyságával, az ODI, RDQ és Zung-kérdőívekkel végeztük. Eredményeink igazolták, hogy a Félelem és Elkerülés Hiedelmek Kérdőív sem az összpontszám, sem külön-külön a fizikai ak-

3. táblázat $\mid A F A B Q-H$ értékeinek korrelációja

\begin{tabular}{|c|c|c|c|c|c|c|c|c|c|}
\hline Változók & $\begin{array}{l}\text { Panaszok } \\
\text { fennállásának } \\
\text { ideje }\end{array}$ & Fájdalom & $\begin{array}{l}\text { Roland- } \\
\text { Morris } \\
\text { Derékfájás } \\
\text { és Funkció- } \\
\text { károsodás } \\
\text { Kérdőív } \\
\text { (RDQ) }\end{array}$ & $\begin{array}{l}\text { Oswestry } \\
\text { Derékfájás } \\
\text { Funkciómérō } \\
\text { Index (ODI) }\end{array}$ & $\begin{array}{l}\text { Zung } \\
\text { Depreszió } \\
\text { Skála }\end{array}$ & $\begin{array}{l}\text { FABQ } \\
\text { aktivitás }\end{array}$ & $\begin{array}{l}\text { FABQ } \\
\text { munka }\end{array}$ & $\begin{array}{l}\text { FABQ } \\
\text { összértéke }\end{array}$ & $\begin{array}{l}\text { Fájdalom } \\
\text { Katasztro- } \\
\text { fizálás } \\
\text { Kérdőív } \\
\text { (PCS) }\end{array}$ \\
\hline $\begin{array}{l}\text { FABQ-H } \\
\text { aktivitás }\end{array}$ & 0,089 & $-0,1831$ & $-0,0435$ & 0,1201 & 0,0492 & 1 & $0,3619^{*}$ & 0,6161 * * & 0,1612 \\
\hline $\begin{array}{l}\text { FABQ-H } \\
\text { munka }\end{array}$ & 0,032 & 0,105 & 0,078 & 0,148 & 0,112 & 0,362 * & & 0,957 * * & 0,382 * \\
\hline $\begin{array}{l}\text { FABQ-H } \\
\text { összértéke }\end{array}$ & 0,055 & 0,032 & 0,053 & 0,162 & 0,109 & $0,616^{* *}$ & 0,957 * * & 1 & $0,373^{*}$ \\
\hline
\end{tabular}

auk $\mathrm{N}=43,{ }^{*} \mathrm{p}<0,05,{ }^{*} \mathrm{p}<0,01$ 
tivitástól, illetve a munkától való félelem tekintetében nem mutatott összefüggést a napi tevékenységekben (ODI) és a mozgásfunkciókban (RDQ) megfigyelhető károsodással. A Zung-kérdőív alapján a depressziós tünetekkel sem mutatott a FABQ-H egyik skálája sem összefüggést. A konvergens validitást a szintén diszfunkcionális gondolatokat mérő PCS-kérdőívvel vizsgáltuk. A katasztrofizálással való összefüggés igazolódott

Adataink a nemzetközi szakirodalomban talált eredményekkel összhangban vannak. A fordított változathoz a fent említett validálási vizsgálatokban saját anyagunkhoz hasonló betegszámmal dolgoztak, kivétel ez alól a japán munka, ahol online kitöltés történt, illetve a német fordítás, amely így részletesebb faktoranalízisre adott lehetőséget. A fájdalomskálát mindenütt felvették. Jelentôs mértékben a japán nyelvú kérdőív mutat eltérést, ahol 2,9 az átlagos fájdalom mérése. Itt azonban egy szélesebb populációt vizsgáltak, nem csak krónikus fájdalomban szenvedőket vettek be. A fájdalom mértékével egyik validálás során sem találtak összefüggést a félelem és elkerülési hiedelmekkel. A Roland-Morris Derékfájás és Funkciókárosodás Kérdőív (RDQ) esetén kissé változatosabbak az eredmények, az eredeti angol verzióban mérsékelt, de nem szignifikáns összefüggést írtak le, és máshol más funkcionális kérdőívek használata során sem mutattak ki egyértelmű összefüggést.

Bár a hangulatot és depresszió mértékét más-más mérőeszközökkel értékelték, de szignifikáns összefüggést sehol nem sikerült egyik vizsgálatban sem kimutatni.

\section{Következtetések}

Vizsgálatunk és a szakirodalmi adatok alapján a félelem és elkerülési magatartás külön rizikófaktora a mozgásszervi krónikus fájdalom kialakulásának és fennmaradásának, ezért felmérése a fájdalmak kialakulása utáni elsőharmadik hónapban javasolt. A betegnek a fájdalommal kapcsolatos hiedelmeinek mérésére a FABQ-H kérdóív magyar nyelvü változata önálló szempontokat értékelő mérőeszköz, valid, jól alkalmazható. A FABQ-H hazai alkalmazása nemcsak kutatási szempontból, hanem a mozgásszervi betegek klinikai ellátása során is hasznos lehet, magas értékek esetén a beteget érdemes betegoktató programba, illetve célzott pszichoterápiás kezelésbe bevonni.

Anyagi támogatás: A szerzők anyagi támogatásban nem részesültek.

Szerzői munkamegosztás: S. E.: A hipotézis kidolgozása, a vizsgálat folytatása, irodalomkutatás, a kézirat szövegezése. S. A.: A hipotézis felállítása, az eredmények értéke- lése, a szöveg végleges formájának elkészítése, lektorálás. A szerzők a cikk végleges változatát elolvasták és jóváhagyták.

Érdekeltségek: A szerzőknek nincsenek érdekeltségeik.

\section{Köszönetnyilvánítás}

Köszönjük Dr. Fáy Veronikának a vizsgálat levezetéséhez nyújtott szakmai támogatását és Dr. Dinya Elek professzor úrnak a statisztikai segítséget.

\section{Irodalom}

[1] European Musculosceletal Surveillance and Information Network. Musculoscelatal health status in Europe. www.eumusc. net/workpackages_wp4.cfm.2006-2010

[2] Illés ST. Low back pain: when and what to do. [A derékfájás: mikor és mit tegyünk?] Orv Hetil. 2015; 156: 1315-1320. [Hungarian]

[3] Waddell G, Newton M, Henderson I. A Fear-Avoidance Beliefs Questionnaire (FABQ) and the role of fear-avoidance beliefs in chronic low back pain and disability. Pain 1993; 52: 157-168.

[4] Wertli MM, Rasmussen-Barr E, Weiser S, et al. The role of fear avoidance beliefs as a prognostic factor for outcome in patients with nonspecific low back pain: a systematic review. Spine J. 2014; 14: 816-836.e4.

[5] Wicksell RK, Olsson GL, Hayes SC. Psychological flexibility as a mediator of improvement in acceptance and commitment therapy for patients with chronic pain following whiplash. Eur J Pain 2010, 14: 1059.el-1059.ell.

[6] Reesor KA, Craig KD. Medically incongruent chronic back pain: physical limitations, suffering and ineffective coping. Pain 1988; 32: 35-45.

[7] Kandel ER. A new intellectual framework for psychiatry. Am J Psychiatry 1998; 155: 457-469.

[8] Davis M. Neural systems involved in fear and anxiety measured with fear-potentiated startle. Am Psychol. 2006; 61: 741-756.

[9] Waddell G, Bircher M, Finlayson D, et al. Symptoms and signs: physical disease or illness behaviour? Br Med J. (Clin Res Ed). 1984; 289: 739-741.

[10] Fordyce WE. Behavioural science and chronic pain. Postgrad Med J. 1984; 60: 865-868.

[11] Kori SH, Miller RP, Todd DD. Kinesiophobia: a new view of chronic pain behaviour. Pain Manag. 1990; 3: 35-43.

[12] Melzack R. The McGill Pain Questionnaire: major properties and scoring methods. Pain 1975; 1: 277-299.

[13] Riley JF, Ahern DK, Follick MJ. Chronic pain and functional impairment: assessing beliefs about their relationship. Arch Phys Med Rehabil. 1988; 69: 579-582.

[14] Jensen MP, Karoly P, Huger R. The development and preliminary validitation of instrument to asses patients' attitudes toward pain. J Psychosom Res. 1987; 31: 393-400.

[15] Philips HC. Avoidance behaviour and its role in sustaining chronic pain. Behav Res Ther. 1987; 25: 273-279.

[16] Swinkels-Meewisse EJ, Swinkels RA, Verbeek AL, et al. Psychometric properties of the Tampa Scale for kinesiophobia and the fear-avoidance beliefs questionnaire in acute low back pain. Man Ther. 2003; 8: 29-36.

[17] Crombez G, Vlaeyen JW, Heuts PH, et al. Pain-related fear is more disabling than pain it self: evidence on the role of pain-re- 
lated fear in chronic back pain disability. Pain 1999; 80: 329339.

[18] Pfingstein M, Kröner-Herwig B, Leibing E, et al. Validation of the German version of the Fear-Avoidance Beliefs Questionnaire. Eur J Pain 2000; 4: 259-266.

[19] Poiraudeau S. Validation of the French version of the Fear Avoidance Belief Questionnaire. Spine (Phila Pa 1976). 2004; 29: 908-913.

[20] Monticone $\mathrm{M}$, Baiardi $\mathrm{P}$, Bonetti $\mathrm{F}$, et al. The Italian version of the Fear-Avoidance Beliefs Questionnaire (FABQ-I): cross-cultural adaptation, factor analysis, reliability, validity, and sensitivity to change. Spine (Phila Pa 1976). 2012; 37: E374-E380.

[21] Matsudaira K, Kikuchi N, Murakami A, et al. Psychometric properties of the Japanese version of the Fear-Avoidance Beliefs Questionnaire (FABQ). J Orthop Sci. 2014; 19: 26-32.

[22] Alanazi F, Gleeson P, Olson S, et al. Translation and validation of the Arabic version of the Fear-Avoidance Beliefs Questionnaire in patients with low back. Spine (Phila Pa 1976). 2017; 42: E411-E416.

[23] Terho H, Haapea M, Paananen M, et al. Translation and validation of the Finnish version of the Fear-Avoidance Beliefs Questionnaire (FABQ). Scand J Pain 2016; 10: 113-118.
[24] Fairbank J, Couper J, Davies J, et al. The Oswestry Low Back Pain Questionnaire. Physiotherapy 1980; 66: 271-273.

[25] Roland M, Morris R. A study of the natural history of low back pain: Part 1. Development of a reliable and sensitive measure of disability in low-back pain. Spine (Phila Pa 1976). 1983; 8: 141144.

[26] Zung WW. A self-rating depression scale. Arch Gen Psychiatr. $1965 ; 12: 63-70$.

[27] Sullivan MJ, Bishop SR, Pivik J. The Pain Catastrophizing Scale: Development and validation. Psychological Assessment 1995; 7 : 524-532.

[28] Kökönyei Gy. Emotion regulation in chronic pain. Doctoral dissertation. [Érzelemszabályozás krónikus fájdalomban. Doktori disszertáció.] ELTE, Pedagógiai és Pszichológiai Kar, Pszichológiatudomány Doktori Iskola, Budapest, 2008; pp. 106110. [Hungarian]

(Simoncsics Eszter dr., Budapest, Jahn Ferenc u. 62-66., 1195 e-mail: esimoncsics@gmail.com)

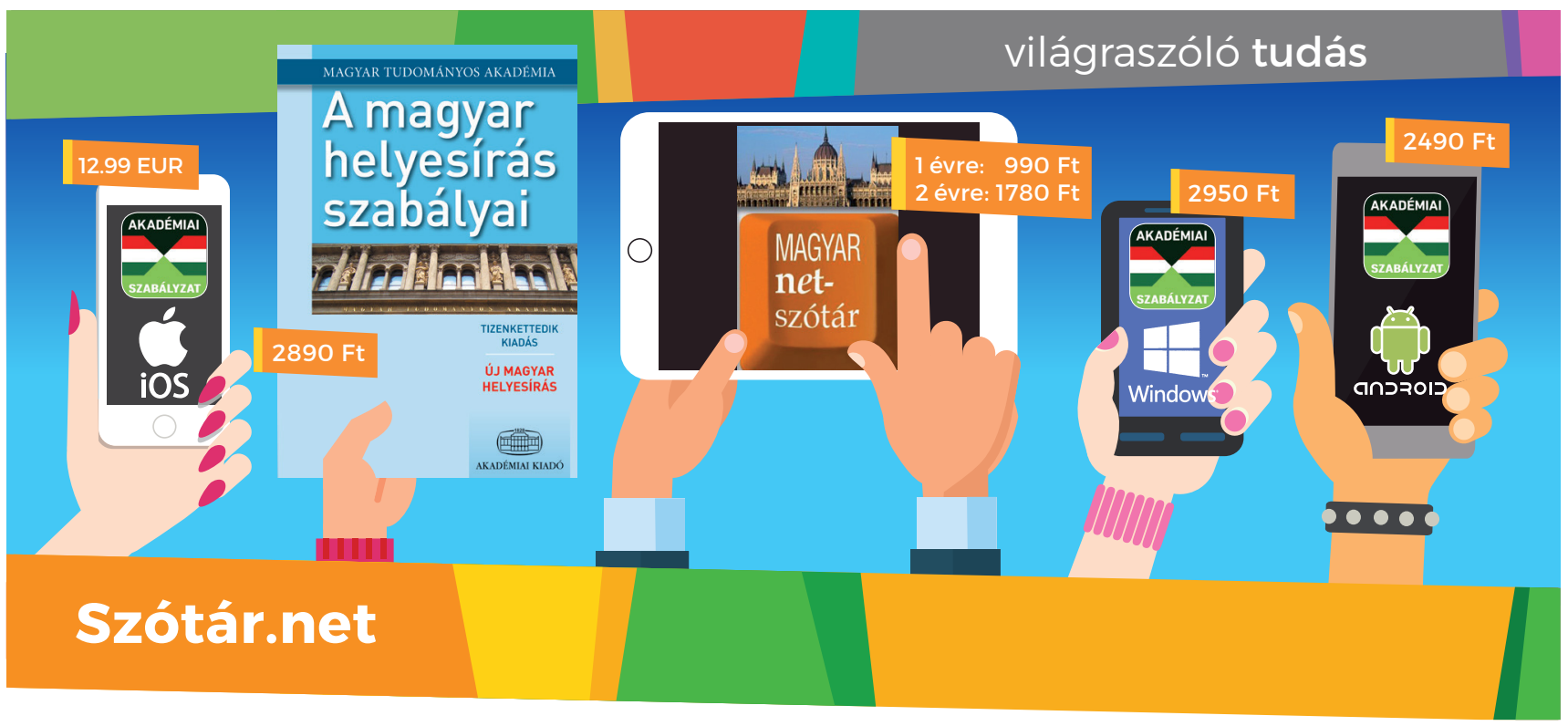

\section{A magyar helyesírás szabályai 12. kiadás}

\section{Mindig a keze ůgyében!}

\section{- a Magyar Tudományos Akadémia szabályzata - 300 szabálypont példákkal - szabályzat és szótár egyben}

\author{
a 11. és a 12. kiadás közti különbségek \\ felsorolása, példákkal \\ - tárgymutató

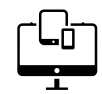

Keresse a könyvet a www.akademiai.hu oldalon, vagy válassza az online változatot és a mobilalkalmazást a www.szotar.net-en!

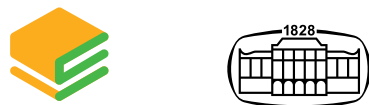

Szótár.net AKADÉMIAI KIADÓ 